\title{
A ligand-based and enediyne-energized bispecific fusion protein targeting epidermal growth factor receptor and insulin-like growth factor-1 receptor shows potent antitumor efficacy against esophageal cancer
}

\author{
HAI-YING CAO ${ }^{1}$, XIAO-FANG GUO ${ }^{1}$, XIAO-FEI ZHU ${ }^{2,3}$, SAI-SAI LI $^{1}$ and YONG-SU ZHEN ${ }^{4}$ \\ ${ }^{1}$ School of Basic Medical Sciences and ${ }^{2}$ School of Laboratory Medicine, Xinxiang Medical University; \\ ${ }^{3}$ Henan Collaborative Innovation Center of Molecular Diagnosis and Laboratory Medicine, Xinxiang, Henan 453003; \\ ${ }^{4}$ Institute of Medicinal Biotechnology, Chinese Academy of Medical Sciences and \\ Perking Union Medical College, Beijing 100050, P.R. China
}

Received September 23, 2016; Accepted January 26, 2017

DOI: $10.3892 /$ or.2017.5606

\begin{abstract}
Recent studies have revealed that the epidermal growth factor receptor (EGFR) and insulin-like growth factor-1 receptor (IGF-1R) are overexpressed in various types of human tumors and are attractive targets for anticancer drugs. In the present study, the expression of EGFR and IGF-1R in esophageal squamous cell carcinoma (ESCC) and adjacent normal tissues in a tissue microarray was firstly detected by immunohistochemical staining. In addition, their co-overexpression was observed in 48 out of $75(64 \%)$ patients. Based on the findings, the antitumor activity of an EGFR/IGF-1R bispecific and enediyne-energized fusion protein EGF-LDP-IGF-AE, which we constructed recently by fusing two ligands (EGF and IGF-1) with an enediyne antibiotic lidamycin (LDM), on ESCC were evaluated. Binding assay indicated that the EGF-LDP-IGF protein bound to esophageal cancer cells, and then internalized into the cytoplasm. In vitro, the enediyne-energized fusion protein EGF-LDP-IGF-AE exhibited extremely potent cytotoxicity to ESCC cells with $\mathrm{IC}_{50}$ values between $10^{-10}$ and $10^{-15} \mathrm{~mol} / \mathrm{l}$. In vivo, EGF-LDP-IGF-AE also markedly suppressed the growth of human KYSE450 xenografts by $75.1 \%$ when administered at $0.3 \mathrm{mg} / \mathrm{kg}$ in a nude mouse model, and its efficacy was significantly higher than that of LDM (at maximum tolerated dosage) and mono-specific counterparts. In addition, EGF-LDP-IGF-AE arrested cell cycle progression
\end{abstract}

Correspondence to: Dr Xiao-Fang Guo, School of Basic Medical Sciences, Xinxiang Medical University, 601 Jinsui Road, Xinxiang, Henan 453003, P.R. China

E-mail: guoxiaofang_1981@126.com

Key words: epidermal growth factor receptor, insulin-like growth factor 1 receptor, crosstalk, esophageal cancer, fusion protein and it concentration-dependently induced cell apoptosis as well as inhibited the activation of EGFR/IGF-1R and two major downstream signaling pathways (PI3K/AKT and RAS/MAPK). These data imply the potential clinical application of EGF-LDP-IGF-AE for ESCC patients with EGFR and/or IGF-1R overexpression.

\section{Introduction}

The morbidity and mortality of esophageal cancer rank the eighth and sixth among all malignant tumors worldwide (1). Esophageal cancer is classified into esophageal squamous cell carcinoma (ESCC) and adenocarcinoma (EAC) based on the histopathologic type. In Western countries, EAC represents the dominant subtype and the incidence has increased markedly over the past decades, whereas the northern regions of Henan Province, China, have the highest incidence of ESCC (2). Despite the great advances in early diagnosis and traditional treatment options (surgery, chemotherapy and radiotherapy), the prognosis of patients with advanced esophageal cancer remains poor with the 5-year survival rate ranging from 15 to $25 \%$ (3). During the past decade, the field of drug development has been transformed with the identification of and ability to direct treatment at specific molecular targets. The overexpression and aberrant function of epidermal growth factor receptor (EGFR) and insulin-like growth factor-1 receptor (IGF-1R) in a number of solid tumors including esophageal cancer, and the important roles in the development of tumors have provided a rationale for targeting the two receptors.

EGFR/HER1 is a member of the ErbB receptor tyrosine kinase family, and there are three other members, HER2, HER3 and HER4, in this family. Ligand (EGF and TGF- $\alpha$ ) binding to the receptors results in receptor homodimerization and heterodimerization, activation of the intrinsic kinase domain and initiation of a cascade of downstream signaling that ultimately promotes tumor cell survival, proliferation, invasion and metastasis (4). EGFR overexpression has been observed in many human tumors, such as lung, head and neck, 
colorectal, breast and ovarian (5-9). In esophageal cancer, $\sim 50-71 \%$ of ESCC patients have EGFR overexpression (10). The IGF system is comprised of the IGF ligands (IGF-1 and IGF-2), cell-surface receptors (IGF-1R and IGF-2R) and six IGF-binding proteins (IGFBPs). IGF-1R is a tetrameric glycoprotein containing two $\alpha$ subunits and two $\beta$ subunits linked by disulfide bonds, and there is a $60 \%$ homology between IGF-1R and the insulin receptor. IGF-1R binds IGF-1 with high affinity and IGF-2 and insulin with a lower affinity. Similarly, when the ligands bind to IGF-1R, auto-phosphorylation of the receptor tyrosine kinase is induced, leading to the activation of multiple downstream signaling pathways, such as PI3K/ AKT and RAS/MAPK, each of which plays an important role in cell proliferation, migration and metabolism. IGF-1R overexpression has also been found in many tumors, including $60 \%$ of esophageal cancer, and its overexpression was found to correlate with advanced tumor stage, depth of invasion, metastasis and recurrence $(11,12)$. IGF-1R and EGFR families show homology in their structure and both the receptors share considerable crosstalk in their functions. Co-expression of the two receptors was observed in resected non-small cell lung cancer (NSCLC), colorectal cancer, adrenocortical carcinoma, pancreatic ductal adenocarcinoma, and was found to be associated with poor pathological stage and shorter diseasefree survival (DFS) (13-16). A number of EGFR-targeted drugs (gefitinib, erlotinib, cetuximab and panitumumab) alone or in combination with chemotherapeutics have been tested clinically for the treatment of patients with esophageal cancer, but the results are disappointing (17-21). Different from the monoclonal antibodies and tyrosine kinase inhibitors, antibody-drug conjugates or ligand-toxin fusion proteins taking advantage of the specificity of antibodies or ligands and the potent cytotoxic activity of toxins have shown elevated antitumor efficacy. Furthermore, they are effective even for patients who are resistant to targeted drugs. For example, trastuzumab emtansine (T-DM1) consisting of trastuzumab coupled to a cytotoxic agent, emtansine (DM1), showed significantly improved progression-free and overall survival with less toxicity than lapatinib plus capecitabine in patients with HER2-positive advanced breast cancer previously treated with trastuzumab and a taxane (22).

EGF-LDP-IGF-AE is a bispecific and enediyne-energized fusion protein targeting both EGFR and IGF-1R that was previously constructed by us (23). It contains two ligands (EGF and IGF-1) specific for EGFR and IGF-1R and an enediyne antibiotic lidamycin (LDM) with potent cytotoxicity. The two ligands were designed as targeting moiety, directing the fusion protein to cancer cells with EGFR and IGF-1R overexpression. LDM is composed of a noncovalently bound apoprotein (LDP) and an active enediyne chromophore (AE) that act as a cytotoxic moiety as previous studies have demonstrated the extremely potent cytotoxicity of LDM to various tumor cells and marked inhibitory effects on a panel of xenografts in athymic mice (24). In the present study, we measured the in vitro and in vivo antitumor activity of EGF-LDP-IGF-AE on esophageal cancer and the efficacy was compared with corresponding mono-specific fusion proteins to determine whether dual inhibition of EGFR and IGF-1R is more efficacious. The underlying mechanisms of the antitumor effect of EGF-LDP-IGF-AE were also evaluated.

\section{Materials and methods}

Ethics statement. All experiments involved in animals were performed according to the Declaration of Helsinki and according to international and national guidelines, and the procedures were approved by the Ethics Committee of Xinxiang Medical University.

Tissue microarray and immunohistochemical staining. Tissue microarrays containing a total of 75 pairs of human ESCC tumor and corresponding adjacent normal tissues (HEsoSqu150CS-01), were purchased from Shanghai Outdo Biotech Co. Ltd. (Shanghai, China), and the immunohistochemical (IHC) staining was used to analyze EGFR and IGF-1R expression. Tissue microarray slides were deparaffinized in xylene, rehydrated with graded ethanol and immersed in water. For antigen retrieval, the slides were heated at $95^{\circ} \mathrm{C}$ for $40 \mathrm{~min}$ and incubated with $3 \%$ hydrogen peroxide at room temperature for $15 \mathrm{~min}$. Mouse anti-EGFR or anti-IGF-1R antibody (diluted 1:100; Lab Vision Corporation, Fremont, CA, USA) was applied overnight at $4^{\circ} \mathrm{C}$, followed by Polymer Helper (ZSGB-Bio, Beijing, China) for $20 \mathrm{~min}$. Subsequently, the slides were incubated with polyperoxidase anti-mouse IgG (ZSGB-Bio) at $37^{\circ} \mathrm{C}$ for $30 \mathrm{~min}$. According to the manufacturer's instructions, the slides were reacted with DAB liquid system (Dako, Glostrup, Denmark) and counterstained with hematoxylin. The assessment of EGFR or IGF-1R staining was performed by two pathologists separately using $\mathrm{H}$-score systems as previously described (25): scores $\geq 201,101-200,1-100,0$ represent strongly positive (3+), moderately positive (2+), weakly positive (1+) and negative (-) staining, respectively.

Cell lines and culture conditions. Human ESCC cell lines EC9706, TE-1, KYSE450 and KYSE510 were obtained from the Cell Center of Peking Union Medical College (Beijing, China). Cells were cultured in RPMI-1640 medium (Gibco; Life Technologies) containing 10\% (v/v) fetal bovine serum (FBS; Gibco, Life Technologies) and $100 \mu \mathrm{g} / \mathrm{ml}$ streptomycin, $100 \mathrm{U} / \mathrm{ml}$ penicillin at $37^{\circ} \mathrm{C}$ with $5 \% \mathrm{CO}_{2}$.

Preparation of fusion proteins and their enediyne-energized analogues. DNA sequences coding for fusion protein EGF-LDP-IGF, which contains the gene of human EGF (169 bp), $\left(\mathrm{G}_{4} \mathrm{~S}\right)_{2}$-linker (30 bp), apoprotein of LDM (ldp, $330 \mathrm{bp}),\left(\mathrm{G}_{4} \mathrm{~S}\right)_{2}$-linker (30 bp) and human IGF-1 (210 bp) from 5' to 3' end, were synthesized by Beijing Sunbiotech Co. Ltd. (Beijing, China), and then, it was cloned into the pET30a vector to generate the plasmid pET30-egf-ldp-igf. EGF-LDP-IGF protein was expressed in the Escherichia coli strain BL21(DE3) according to the pET System Manual (11th edition; Novagen, Madison, WI, USA) and purified by $\mathrm{Ni}^{2+}$ affinity chromatography (HisTrap HP column; GE Healthcare, Milwaukee, WI, USA), since the $\mathrm{His}_{6}$-tag was introduced to the $\mathrm{COOH}$ terminal of EGF-LDP-IGF protein. The active chromophore of LDM (AE) was isolated using a C4 column (GE Healthcare) with $22 \%$ acetonitrile in $0.05 \%$ trifluoroactic acid mobile phase, and then the enediyne-energized analogue of fusion protein EGF-LDP-IGF-AE was prepared by integrating the AE into EGF-LDP-IGF. The corresponding mono-specific fusion proteins (EGF-LDP and LDP-IGF) 
and their enediyne-energized analogues (EGF-LDP-AE and LDP-IGF-AE) were constructed in the same way.

Binding affinity assay. The binding affinity of EGF-LDP-IGF protein to esophageal cancer cells was analyzed by immunofluorescence staining assay. Cells were grown on coverslips, cultured for $24 \mathrm{~h}$ and fixed with $4 \%$ paraformaldehyde for $10 \mathrm{~min}$ at room temperature. After washed three times with $0.05 \%$ Tween-20 in phosphate-buffered saline (PBS) for 5 min each, the cells were blocked with $5 \%$ bovine serum albumin (BSA; Genview, China) for $1 \mathrm{~h}$ and subsequently incubated with EGF-LDP-IGF protein $(50 \mu \mathrm{g} / \mathrm{ml})$ for $2 \mathrm{~h}$ at room temperature. Then, they were incubated with mouse anti-His-tag antibody (diluted 1:100; Tiangen Biotech, China) overnight at $4^{\circ} \mathrm{C}$, washed for three times, followed by Alexa Flour 488-labeled goat anti-mouse antibody (diluted 1:50; Beyotime Biotechnology, Shanghai, China) for $1 \mathrm{~h}$. After being washed five times with PBS, the cells were stained with Hoechst 33258 (Beyotime Biotechnology) for $15 \mathrm{~min}$ at room temperature. The images were observed under a Zeiss LSM 780 confocal laser scanning microscope (Carl Zeiss, Jena, Germany).

Cell viability assay. MTT assays were used to measure the cytotoxicity of enediyne-energized fusion proteins to esophageal cancer cells in vitro. Cells were seeded in 96-well plates $\left(1,000-2,000\right.$ cells/well) and incubated for $24 \mathrm{~h}$ at $37^{\circ} \mathrm{C}$ with $5 \% \mathrm{CO}_{2}$. LDM and enediyne-energized fusion proteins (EGF-LDP-IGF-AE, EGF-LDP-AE and LDP-IGF-AE) at different concentrations were added to each well for $48 \mathrm{~h}$ of incubation. Then, $20 \mu 1 \mathrm{MTT}$ ( $5 \mathrm{mg} / \mathrm{ml}$; Sigma) was subsequently added and incubated for another $4 \mathrm{~h}$. The supernatant was removed and $150 \mu 1$ dimethyl sulfoxide (DMSO) was added to each well. The absorbance at $570 \mathrm{~nm}$ was measured by an ELISA reader (Thermo Fisher Scientific, Inc., Waltham, MA, USA). Growth inhibition was calculated as the percentage of the untreated controls and the $\mathrm{IC}_{50}$ values were calculated by GraphPad Prism 5.

Cell cycle distribution analysis. Propidium iodide (PI) staining was used for evaluating the effects of bispecific fusion protein EGF-LDP-IGF-AE on cell cycle distribution. Cells $\left(2 \times 10^{4}\right)$ were plated in $60-\mathrm{mm}$ dishes, cultured for $24 \mathrm{~h}$ and treated with $0.01,0.05$ and $0.1 \mathrm{nmol} / 1$ EGF-LDP-IGF-AE for $48 \mathrm{~h}$. Subsequently, the cells were digested by trypsin-EDTA and fixed with cold $70 \%$ ethanol. After being washed three times with PBS, the cells were resuspended in $500 \mu 1$ staining buffer containing PI $(50 \mathrm{mg} / \mathrm{ml}, 25 \mu \mathrm{l})$ and RNase A $(100 \mathrm{mg} /$ $\mathrm{ml}, 10 \mu \mathrm{l})$ and incubated at $37^{\circ} \mathrm{C}$ for $30 \mathrm{~min}$ according to the manufacturer's instructions (Beyotime Biotechnology). Then, cells were analyzed for fluorescence with a flow cytometer (BD Biosciences, Heidelberg, Germany).

Cell apoptosis assay. The effect of EGF-LDP-IGF-AE on the apoptosis of esophageal cancer cells was investigated by Annexin V-FITC/PI staining. Cells were cultured in 6-well plates for $24 \mathrm{~h}$ and treated with $0.1,0.5,1$ and $2 \mathrm{nmol} / \mathrm{l}$ of EGF-LDP-IGF-AE for $48 \mathrm{~h}$. Cells were harvested, washed twice with PBS, resuspended in $500 \mu 1$ binding buffer containing $10 \mu \mathrm{l}$ Annexin V-FITC and $5 \mu \mathrm{l}$ PI (Beyotime
Biotechnology), incubated at room temperature for $10 \mathrm{~min}$, and analyzed for fluorescence with a flow cytometer (BD Biosciences).

Western blot analysis. KYSE450 or EC9706 cells were seeded in $100-\mathrm{mm}$ dishes and grown to $70-80 \%$ confluence, after which the cells were washed twice in PBS and cultured overnight in serum-free medium. Cells were firstly exposed to EGF-LDP-IGF-AE $(0.1 \mathrm{nmol} / \mathrm{l})$, EGF-LDP-AE $(0.1 \mathrm{nmol} / \mathrm{l})$ or LDP-IGF-AE $(0.1 \mathrm{nmol} / \mathrm{l})$ for $24,48,72$ or $96 \mathrm{~h}$, followed by stimulation with human EGF (50 ng/ml), human IGF-1 $(50 \mathrm{ng} / \mathrm{ml})$ (both from Abcam, Cambridge, MA, USA), or both for $30 \mathrm{~min}$ at $37^{\circ} \mathrm{C}$. Cells were then collected and lysed in cell lysis buffer (Beyotime Biotechnology) containing $1 \mathrm{mmol} / 1$ phenylmethylsulfonyl fluoride (PMSF) on ice for $30 \mathrm{~min}$. Total proteins $(30 \mu \mathrm{g})$ extracted from the cells were applied on 10\% SDS-PAGE and transferred to polyvinylidenedifluoride membranes (PVDF; Millipore, Billerica, MA, USA). After being blocked with 5\% BSA for $1 \mathrm{~h}$ at room temperature, the membranes were incubated with primary antibodies (diluted 1:1,000) overnight at $4^{\circ} \mathrm{C}$ and secondary HRP-conjugated antibodies (diluted 1:4,000) (both from Cell Signaling Technology, Beverly, MA, USA) for $1 \mathrm{~h}$ after being washed three times with 1X TBST buffer. The specific bands were visualized with the Immobilon Western Chemiluminescent HRP Substrate kit (Millipore) and captured by Amersham Imager 600 system (GE Healthcare, Logan, UT, USA).

In vivo efficacy assay. Female BALB/c nude mice were purchased from Vital River Laboratory Animal Technology Co. Ltd. (Beijing, China), and the KYSE450 xenograft nude mouse model was performed to evaluate the in vivo efficacy of fusion proteins. KYSE450 cells $\left(5 \times 10^{7}\right)$ suspended in $200 \mu \mathrm{l}$ PBS were inoculated s.c. in the right armpit of nude mice. When the tumor size was $>100 \mathrm{~mm}^{3}$, the nude mice were randomly divided into six groups $(\mathrm{n}=6)$ and treated with EGF-LDP-AE $(0.3 \mathrm{mg} / \mathrm{kg})$, LDP-IGF-AE $(0.3 \mathrm{mg} / \mathrm{kg})$, EGF-LDP-IGF-AE $(0.2$ and $0.3 \mathrm{mg} / \mathrm{kg})$ and $\mathrm{LDM}(0.05 \mathrm{mg} / \mathrm{kg})$, respectively. They received a $200 \mu \mathrm{l}$ volume of PBS and injected i.v. in the tail vein. Ten days after the first treatment, tumor-bearing mice were injected with the fusion proteins again at the same doses. Tumor size was measured every third day and tumor volume (V) was determined using the formula: $\mathrm{V}=$ length $\mathrm{x} \mathrm{width}^{2} / 2$. The inhibition rates were calculated using the formula: 1 - tumor volume (treated)/tumor volume (control) x 100\%.

Statistical analysis. Results of the present study were derived from three independent experiments, analyzed by GraphPad Prism 5 software, and are presented as mean \pm SD. One-way ANOVA or two-way ANOVA and Bonferroni post hoc analysis were used to compare the differences between groups. P-values $<0.05$ were considered as statistically significant. The densitometry analysis of the western blot results was analyzed by ImageJ software.

\section{Results}

EGFR and IGF-IR are overexpressed in esophageal cancer tissues. As shown in Fig. 1A and B, there was strong and specific expression of both EGFR and IGF-1R in the ESCC 
Table I. EGFR and IGF-1R expression in esophageal squamous cell carcinoma and paired normal esophageal tissues in a tissue microarray.

\begin{tabular}{|c|c|c|c|c|}
\hline Tissue & EGFR expression & $\mathrm{n}(\%)$ & IGF-1R expression & $\mathrm{n}(\%)$ \\
\hline \multirow[t]{5}{*}{ Esophageal squamous cell carcinoma } & Negative & $16(21.3)^{\mathrm{a}}$ & Negative & $13(17.3)^{\mathrm{b}}$ \\
\hline & Positive & $59(78.7)^{\mathrm{a}}$ & Positive & $62(82.7)^{\mathrm{b}}$ \\
\hline & Low $(1+)$ & $47(62.7)$ & Low $(1+)$ & $39(50.7)$ \\
\hline & Medium (2+) & $12(16.0)$ & Medium $(2+)$ & $17(24.0)$ \\
\hline & High $(3+)$ & $0(0.0)$ & High $(3+)$ & $6(8.0)$ \\
\hline \multirow[t]{5}{*}{ Paired normal esophageal epithelium } & Negative & $48(64)^{\mathrm{a}}$ & Negative & $38(55.1)^{\mathrm{b}}$ \\
\hline & Positive & $27(36)^{\mathrm{a}}$ & Positive & $31(44.9)^{\mathrm{b}}$ \\
\hline & Low $(1+)$ & $26(33.4)$ & Low $(1+)$ & $26(37.7)$ \\
\hline & Medium (2+) & $1(1.3)$ & Medium $(2+)$ & $5(7.2)$ \\
\hline & $\operatorname{High}(3+)$ & $0(0.0)$ & High $(3+)$ & $0(0.0)$ \\
\hline
\end{tabular}

EGFR and IGF-1R expression levels were evaluated by H-score test after immunohistochemical staining, and for H-score test: negative=0, low $=1-100$, medium $=101-200$, high $\geq 201$. The samples of paired normal esophageal epithelium used for IGF-1R expression were 69 due to the tissue detachment in six samples. ${ }^{a} \mathrm{P}<0.0001$, the difference between EGFR-positive and -negative cases between esophageal squamous cell carcinoma and normal esophageal epithelium was analyzed for significance by Chi-square test. ${ }^{b} \mathrm{P}<0.0001$, the difference in IGF-1R-positive and -negative cases between esophageal squamous cell carcinoma and normal esophageal epithelium was analyzed for significance using Chi-square test. EGFR, epidermal growth factor receptor; IGF-1R, insulin-like growth factor-1 receptor.

tissues. The negative and positive cases for EGFR in ESCC tissues were 16 and 59, respectively, which were significantly different from the paired adjacent normal tissues (the negative and positive cases of 48 and 27, respectively; Chi-square test, $\mathrm{P}<0.0001)$. The expression of IGF-1R in the ESCC and paired adjacent normal tissues was also significantly different (Chi-square test, $\mathrm{P}<0.0001$; Table I). The EGFR and IGF-1R expression results from the tissue microarray are summarized in Table I, and representative examples of negative and positive staining with intensities of $1+, 2+$ and $3+$ are presented in Fig. 1C. EGFR expression was positive in $78.67 \%$ of the tumor tissues (59/75), and IGF-1R expression was positive in $82.67 \%$ of the tumor tissues $(62 / 75)$. Furthermore, 48 samples (64\%) exhibited EGFR and IGF-1R co-expression.

Preparation of enediyne-energized fusion proteins. The fusion protein EGF-LDP-IGF, EGF-LDP and LDP-IGF were constructed, extracted and purified according to our previous approach (26). The enediyne-energized analogues of fusion proteins EGF-LDP-IGF-AE, EGF-LDP-AE and LDP-IGF-AE were generated after the active chromophore (AE) of LDM was assembled into fusion proteins. Four enediyne-energized fusion proteins were successfully prepared as measured by reverse-phase HPLC (23).

Binding affinity of the fusion protein EGF-LDP-IGF to ESCC cells. The binding affinity of EGF-LDP-IGF to ESCC cells was analyzed by immunofluorescence staining. KYSE450 cells with high EGFR and IGF-1R expression were incubated with EGF-LDP-IGF protein. Following incubation with anti-His-tag antibody and Alexa Flour 488-labeled antibody, the cells were observed under a confocal laser scanning microscope. As shown in Fig. 2, there was green florescence located on the membrane and cytoplasm of the KYSE450 cells which indicated that the EGF-LDP-IGF protein was able to bind with the receptors on the cell membrane, and then internalized into the cytoplasm through receptor-mediated endocytosis.

Cytotoxicity of enediyne-energized fusion proteins in vitro. The cytotoxicity of the bispecific fusion protein EGF-LDP-IGF-AE on four ESCC cell lines was assessed by MTT assays. The naked LDM and corresponding mono-specific proteins (EGF-LDP-AE and LDP-IGF-AE) were also tested for comparison. The bispecific protein EGF-LDP-IGF-AE exhibited potent cytotoxic effect on the different ESCC cell lines with $\mathrm{IC}_{50}$ values between $10^{-10}$ and $10^{-15} \mathrm{~mol} / \mathrm{l}$ (Fig. 3A and B). LDM and mono-specific enediyneenergized fusion proteins EGF-LDP-AE and LDP-IGF-AE also showed strong cytotoxic activity against the four ESCC cell lines. The $\mathrm{IC}_{50}$ values analyzed by one-way ANOVA and Dunnett's multiple comparison tests revealed that there were significant differences between EGF-LDP-IGF-AE and LDM in the KYSE450 $(\mathrm{P}<0.001)$ and EC9706 cells $(\mathrm{P}<0.05)$. In KYSE510 cells, the differences were significant for EGF-LDP-IGF-AE vs. LDM (P<0.001), EGF-LDP-IGF-AE vs. EGF-LDP-AE $(\mathrm{P}<0.001)$ and EGF-LDP-IGF-AE vs. LDP-IGF-AE $(\mathrm{P}<0.01)$ (Fig. 3B).

To elucidate whether the phosphorylation and total expression level of EGFR and IGF-1R in the ESCC cells was related to the cytotoxicity of EGF-LDP-IGF-AE, we detected the levels of phospho(p)-EGFR, p-IGF-1R and total EGFR, IGF-1R in the four different ESCC cell lines using western blot assay, followed by densitometry analysis of the band intensity by ImageJ software, and the correlation analysis was carried out using Prism 5 software. The results revealed that there was no significant correlation between the $\mathrm{IC}_{50}$ 
A

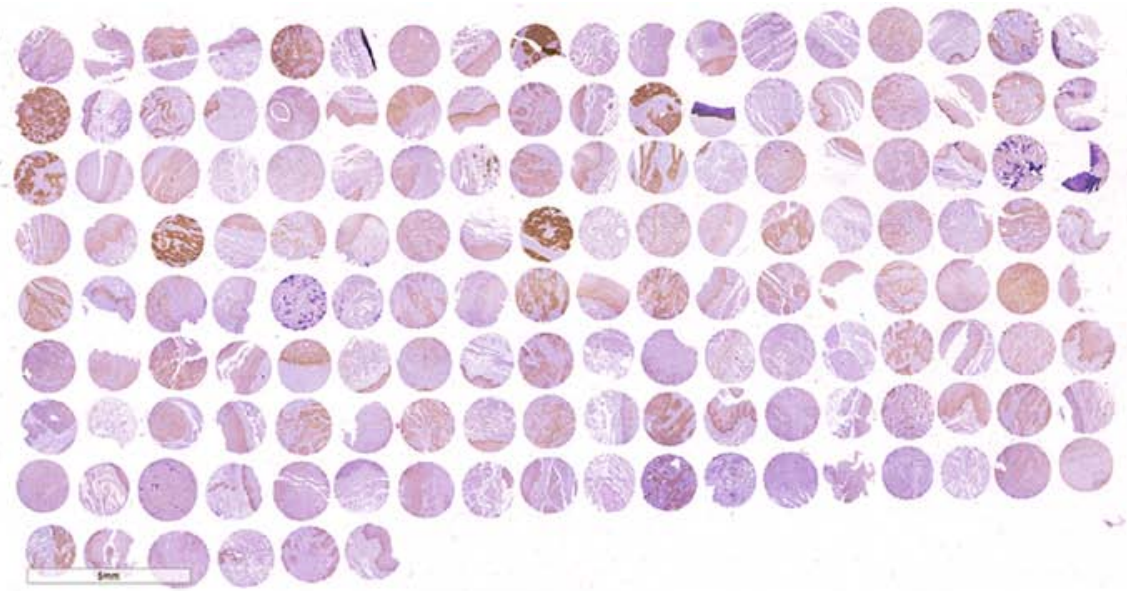

\section{B}

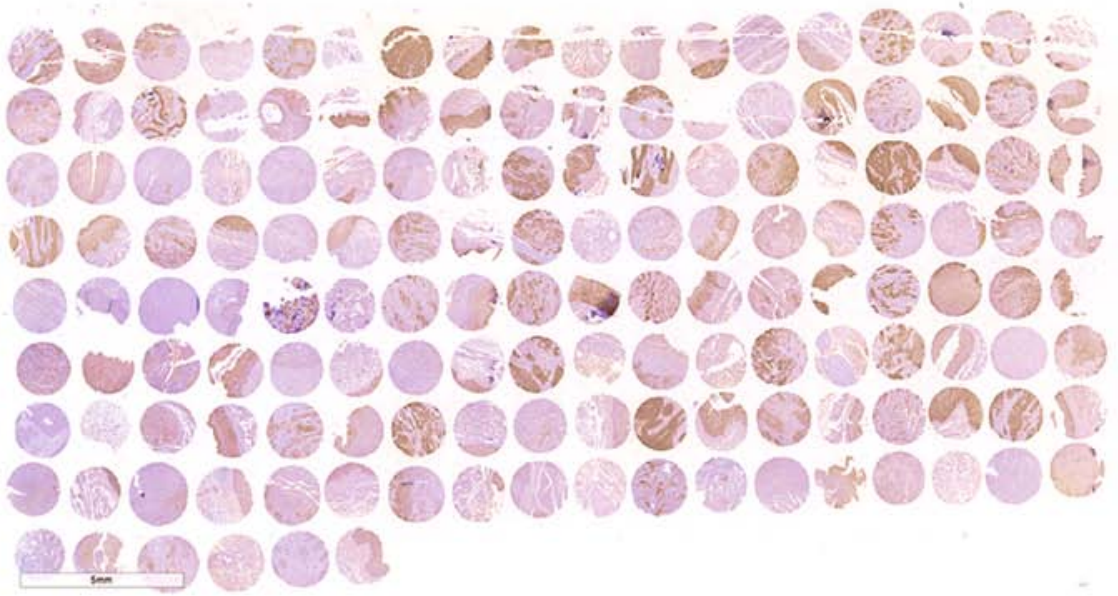

C

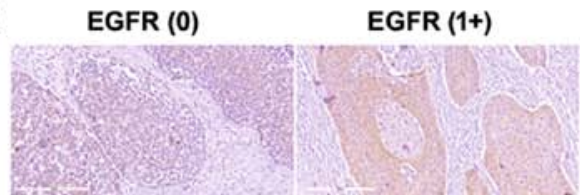

IGF-1R (0)

IGF-1R (1+)

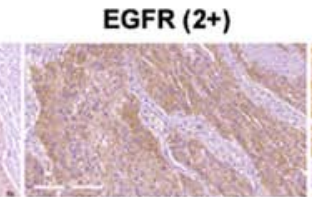

EGFR (3+)

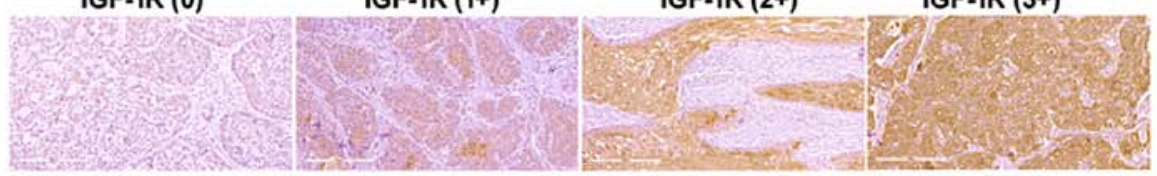

Figure 1. Immunohistochemical analysis of EGFR and IGF-1R expression in ESCC tissue microarrays. Overview of (A) EGFR and (B) IGF-1R expression patterns in ESCC tissue microarrays. Column 1, 3, 5, 7, 9, 11, 13, 15 and 17 include samples of ESCC tissues. Column 2, 4, 6, 8, 10, 12, 14, 16 and 18 include samples of paired adjacent normal tissues. (C) Representative examples of negative and positive staining with intensities of 1+, 2+ and 3+ for EGFR and IGF-1R expression. The images were observed under a microscope at a magnification of $\times 200$.
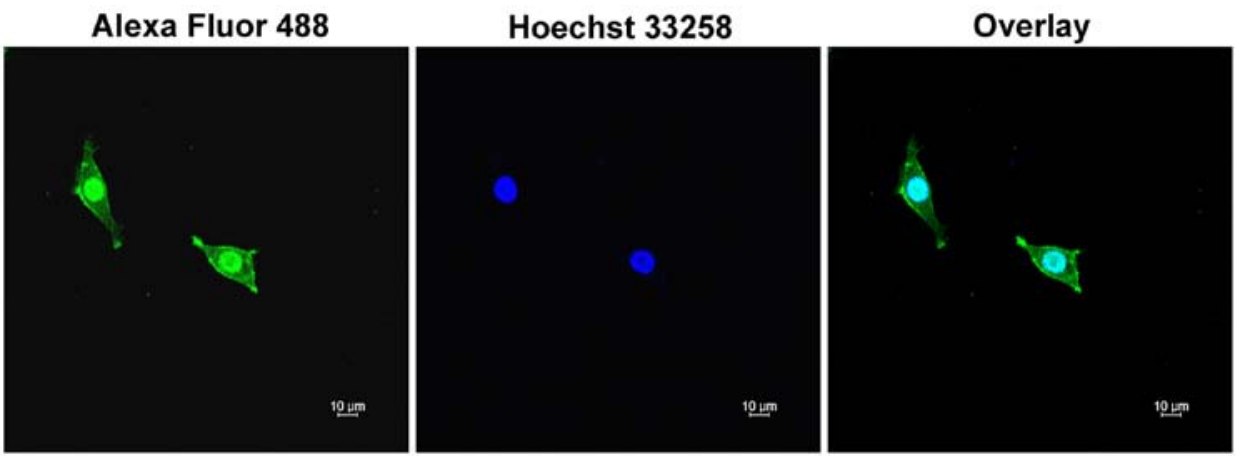

Figure 2. Binding affinity of EGF-LDP-IGF protein to esophageal cancer cells as analyzed by immunofluorescent staining. KYSE450 cells were incubated with EGF-LDP-IGF protein and then exposed to mouse anti-His-tag antibody and Alexa Flour 488-labeled goat anti-mouse antibody. The cell nuclei were stained with Hoechst 33258. Cells were observed under a confocal laser scanning microscope. 
A
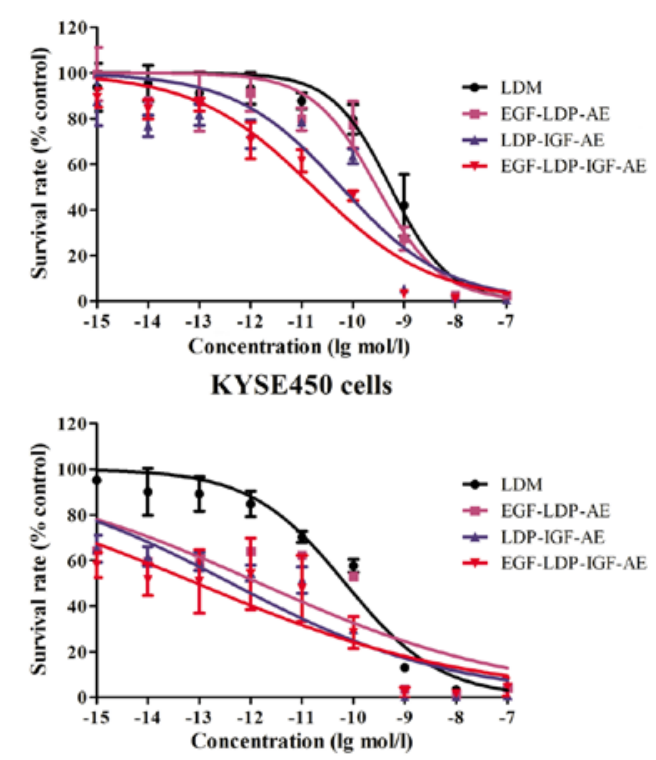

B

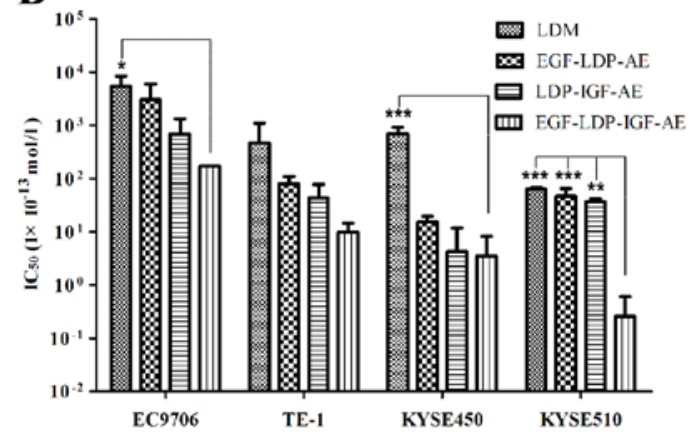

TE-1 cells
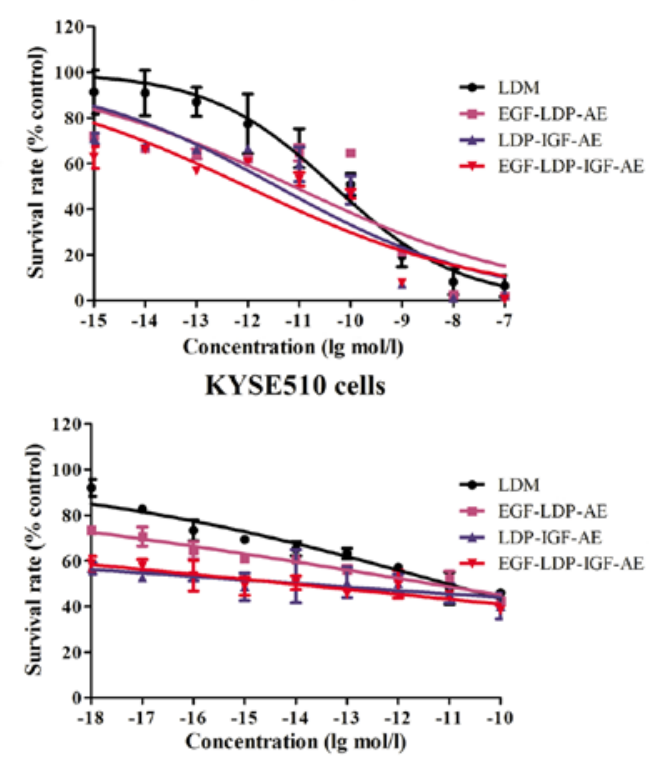

C

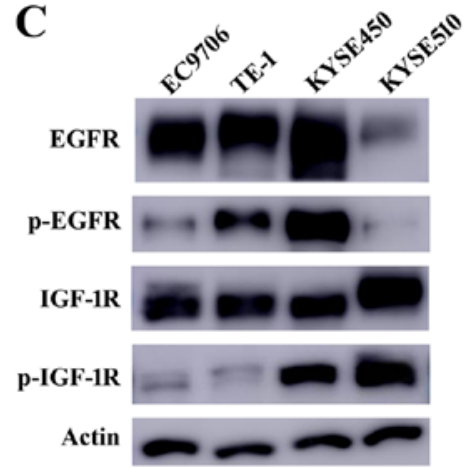

Figure 3. (A) Cytotoxicity of lidamycin (LDM) and enediyne-energized fusion proteins EGF-LDP-IGF-AE, EGF-LDP-AE and LDP-IGF-AE to esophageal cancer cells as determined by MTT assays. (B) The $\mathrm{IC}_{50}$ values of LDM, EGF-LDP-IGF-AE, EGF-LDP-AE and LDP-IGF-AE on four ESCC cell lines. All the results were obtained from three independent experiments, and the data are presented as means $\pm \mathrm{SD}$; ${ }^{*} \mathrm{P}<0.05$ vs. EGF-LDP-IGF-AE, ${ }^{* *} \mathrm{P}<0.01 \mathrm{vs}$. EGF-LDP-IGF-AE, ${ }^{* * *} \mathrm{P}<0.001$ vs. EGF-LDP-IGF-AE. (C) The phosphorylation and total expression levels of EGFR and IGF-1R in the different ESCC cell lines as analyzed by western blot analysis.

Table II. Phosphorylation and total expression levels of EGFR and IGF-1R in ESCC cell lines and the $\mathrm{IC}_{50}$ values for EGFLDP-IGF-AE against different ESCC cell lines.

Western blot analysis

Receptor expression (\% actin)

\begin{tabular}{|c|c|c|c|c|c|}
\hline \multirow[b]{2}{*}{ Cell line } & \multirow{2}{*}{$\begin{array}{l}\text { EGF-LDP-IGF-AE } \\
\mathrm{IC}_{50}(\mathrm{~mol} / \mathrm{l}) \pm \mathrm{SD}\end{array}$} & \\
\hline & & EGFR & p-EGFR & IGF-1R & p-IGF-1R \\
\hline EC9706 & $(7.44 \pm 0.07) \times 10^{-12}$ & 1.13 & 0.36 & 0.83 & 0.26 \\
\hline TE-1 & $(5.83 \pm 0.02) \times 10^{-13}$ & 1.08 & 1.07 & 1.09 & 0.22 \\
\hline KYSE450 & $(8.47 \pm 0.98) \times 10^{-14}$ & 0.91 & 1.18 & 1.22 & 1.17 \\
\hline KYSE510 & $(1.19 \pm 0.04) \times 10^{-15}$ & 0.56 & 0.18 & 1.36 & 1.20 \\
\hline
\end{tabular}

Quantitative analysis of phospho(p)-EGFR, p-IGF-1R, EGFR and IGF-1R was derived from the results of western blotting in Fig. 3C using ImageJ software. EGFR, epidermal growth factor receptor; IGF-1R, insulin-like growth factor-1 receptor; ESCC, esophageal squamous cell carcinoma.

values of EGF-LDP-IGF-AE and the p-EGFR/IGF-1R or total-EGFR/IGF-1R expression levels (Fig. 3C; Table II).
Effects of bispecific fusion protein EGF-LDP-IGF-AE on cell cycle distribution. After treatment with 0.01, 0.05 and 


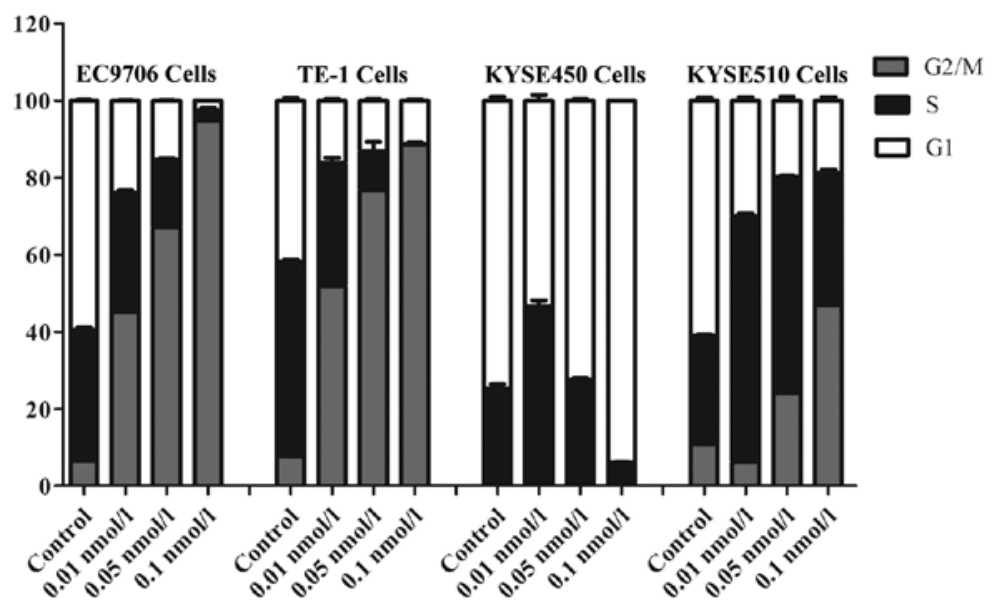

Figure 4. Cell cycle distribution of esophageal cancer cells after treatment with EGF-LDP-IGF-AE at the indicated concentrations for $48 \mathrm{~h}$. Cells distributed in the G1, S and G2/M phases were determined by flow cytometry after PI staining. Results are from three independent experiments and data are presented as means $\pm \mathrm{SD}$.

EC9706 cells

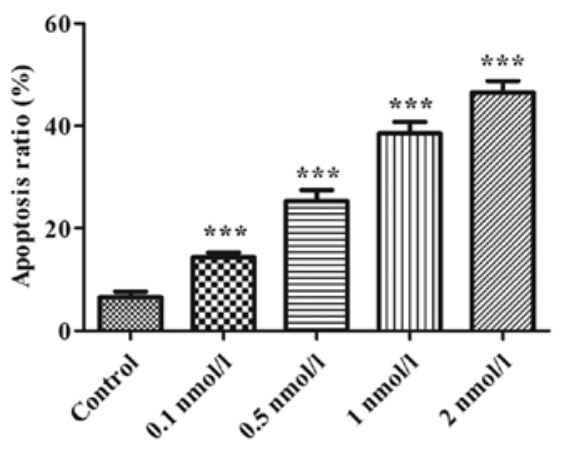

KYSE450 cells

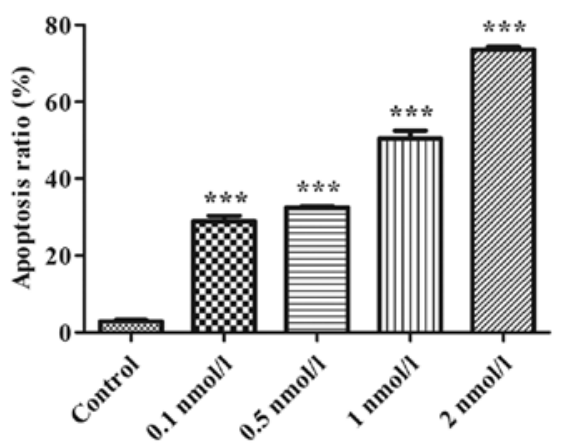

TE-1 cells

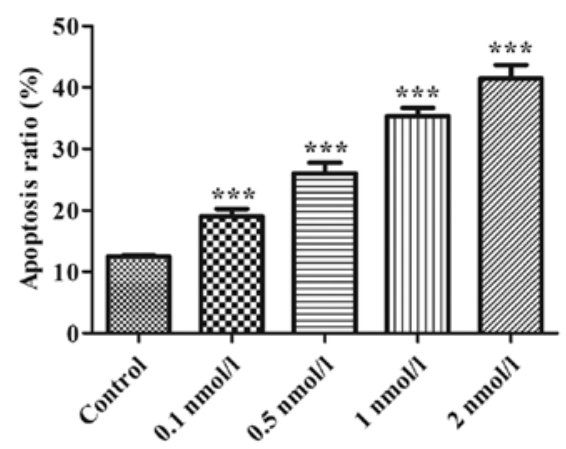

KYSE510 cells

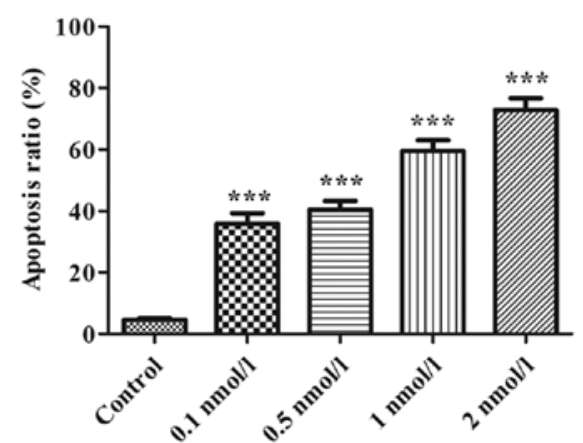

Figure 5. Effects of EGF-LDP-IGF-AE on cell apoptosis. Four ESCC cell lines were exposed to EGF-LDP-IGF-AE for $48 \mathrm{~h}$ at the indicated concentrations and the apoptotic cells were detected by flow cytometry after being stained with Annexin V-FITC and PI. Apoptosis ratios are the sum of early apoptotic and late apoptotic cells; ${ }^{* * *} \mathrm{P}<0.01$ (EGF-LDP-IGF-AE vs. control).

$0.1 \mathrm{nmol} / \mathrm{l}$ of EGF-LDP-IGF-AE for $48 \mathrm{~h}$, the ESCC cell lines were stained using PI and the fluorescence was assessed by a flow cytometer. The changes in cell cycle distribution are shown in Fig. 4. The percentages of control cells (EC9706, TE-1 and KYSE510) distributed in the G2/M phase were $6.48 \pm 0.78,7.70 \pm 0.16$ and $10.87 \pm 0.68 \%$, respectively, whereas the percentages of the cells exposed to $0.1 \mathrm{nmol} / 1$ of EGF-LDPIGF-AE which distributed in the $\mathrm{G} 2 / \mathrm{M}$ phase were $94.78 \pm 0.53$, $88.73 \pm 0.42$ and $46.82 \pm 2.28 \%$, respectively. These data illustrated that a significant $\mathrm{G} 2 / \mathrm{M}$ arrest was caused by the EGF-LDP-IGF-AE treatment in the three cell lines. However, data for the KYSE450 cells indicated that an obvious G1 arrest resulted from $0.1 \mathrm{nmol} / 1$ of EGF-LDP-IGF-AE treatment (93.85\%, $0.1 \mathrm{nmol} / 1$ EGF-LDP-IGF-AE treatment vs. $74.6 \%$, control).

Effects of bispecific fusion protein EGF-LDP-IGF-AE on cell apoptosis. The results of Annexin V-FITC/PI staining 
A

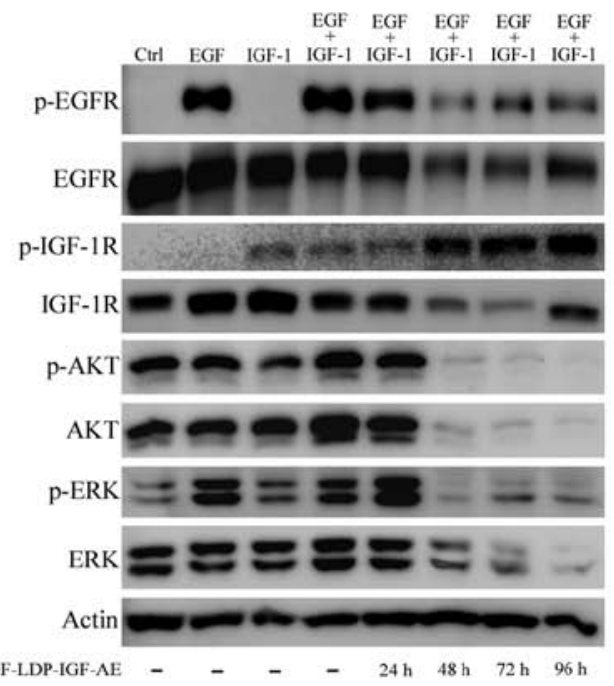

B

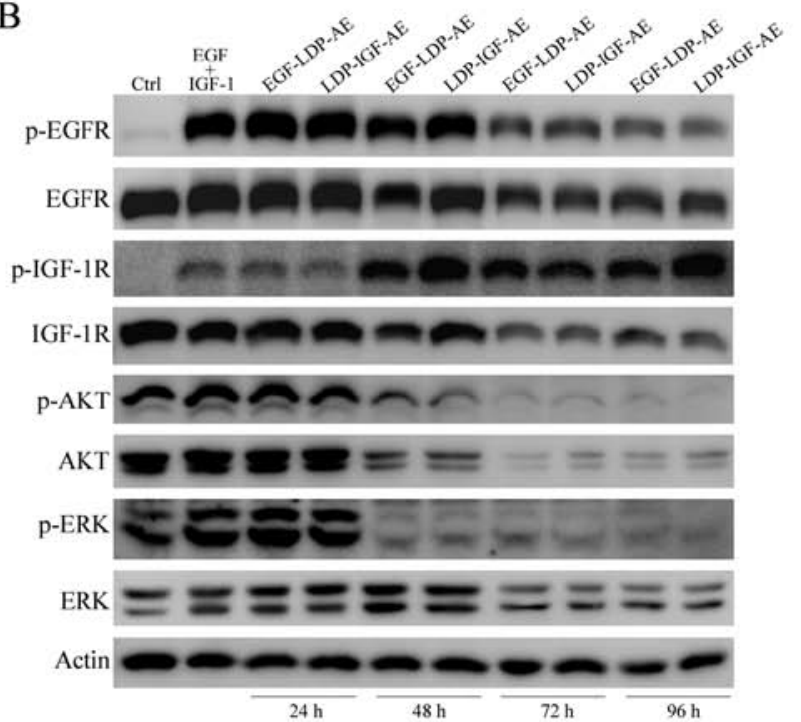

$\mathrm{C}$

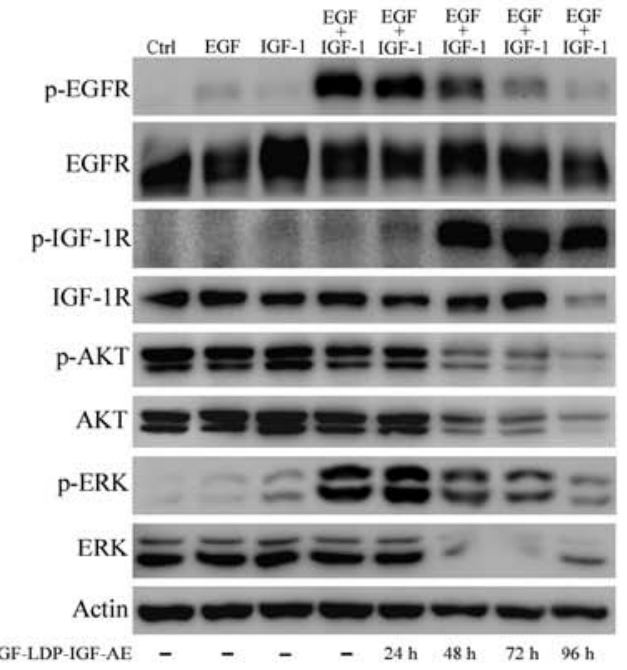

D

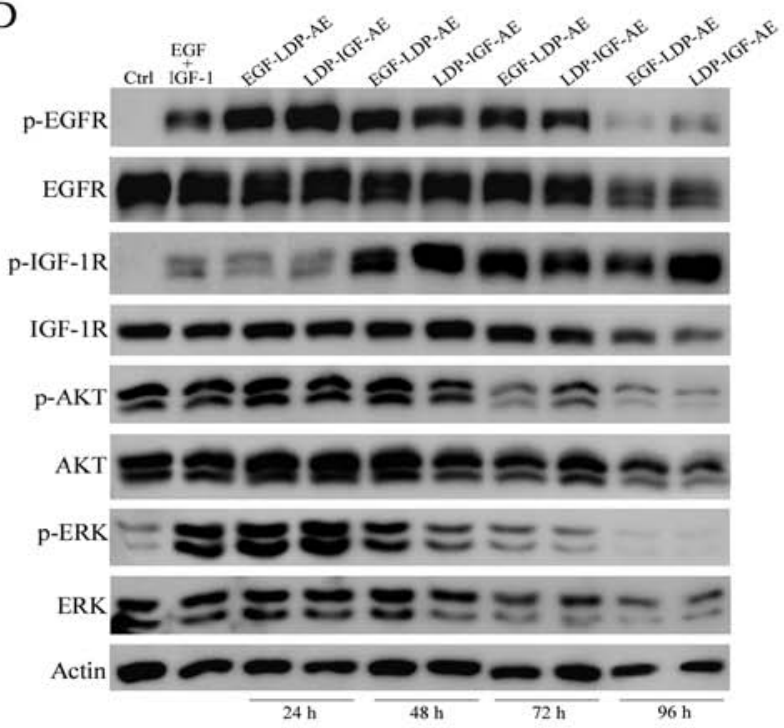

Figure 6. Effects of EGF-LDP-IGF-AE on the EGFR and IGF-1R signaling pathways. (A and C) KYSE450 or EC9706 cells were treated with $0.1 \mathrm{nmol} / 1$ EGF-LDP-IGF-AE for 24, 48, 72 and $96 \mathrm{~h}$. (B and C) KYSE450 or EC9706 cells were treated with EGF-LDP-AE or LDP-IGF-AE for 24, 48,72 and $96 \mathrm{~h}$. Then, the cells were stimulated with human EGF, IGF-1 or both for $30 \mathrm{~min}$. The expression level of key molecules in the EGFR/IGF-1R signaling pathways (e.g. phosphorylated(p)-EGFR, p-IGF-1R, p-ERK and p-AKT) and total EGFR, IGF-1R, ERK and AKT were determined using western blot analysis. $\beta$-actin was regarded as a loading control.

assays revealed that the percentages of apoptotic cells (four ESCC cell lines) increased significantly in a concentrationdependent manner after treatment with EGF-LDP-IGF-AE for $48 \mathrm{~h}$. As shown in Fig. 5, the percentages of apoptotic EC9706 cells after treatment with 0.1, 0.5, 1 and $2 \mathrm{nmol} / \mathrm{l}$ of EGF-LDP-IGF-AE were $14.32 \pm 0.94,25.35 \pm 2.12,38.53 \pm 2.22$ and $46.54 \pm 2.23 \%$, respectively, which indicated a marked increase compared with that of the control cells $(6.56 \pm 1.08 \%$; $\mathrm{P}<0.01)$. Similar results were also obtained in the other ESCC cell lines (TE-1, KYSE450 and KYSE510) after treatment with EGF-LDP-IGF-AE.

Effects of bispecific fusion protein EGF-LDP-IGF-AE on the activation of EGFR and IGF-1R signaling pathways. EGFR and IGF-1R phosphorylation and downstream signal transduction stimulated by EGF and IGF-1 was regulated by treatment with the EGF-LDP-IGF-AE protein. In addition, the effect of EGF-LDP-IGF-AE on the EGFR/IGF-1R signaling pathways was closely related to the treatment time. As shown in Fig. 6A and C, in both the KYSE450 and EC9706 cells, the phosphorylation of EGFR and IGF-1R and the two key downstream signaling molecules, AKT and p44/42 MAPK (ERK), as well as their total expression levels were not affected by the EGF-LDP-IGF-AE treatment for $24 \mathrm{~h}$. However, a significant decrease in p-EGFR, p-AKT and p-ERK was observed with the extension of exposure time (48, 72 and $96 \mathrm{~h}$ ). Interestingly, treatment of EGF-LDP-IGF-AE for 48,72 and $96 \mathrm{~h}$ resulted in a marked increase in p-IGF-1R. The total EGFR and IGF-1R expression levels were decreased after exposure to EGF-LDP-IGF-AE for 48 and $72 \mathrm{~h}$ in the KYSE450 cells, but their expression remained unchanged in the EC9706 cells (except for the reduction of total IGF-1R when treated with EGF-LDP-IGF-AE for $96 \mathrm{~h}$ ). EGF-LDPIGF-AE treatment for 48,72 and $96 \mathrm{~h}$ also resulted in a 
A

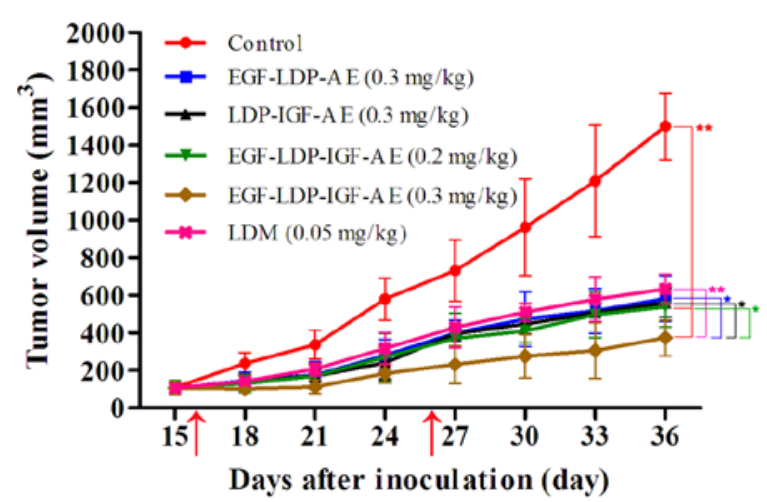

B

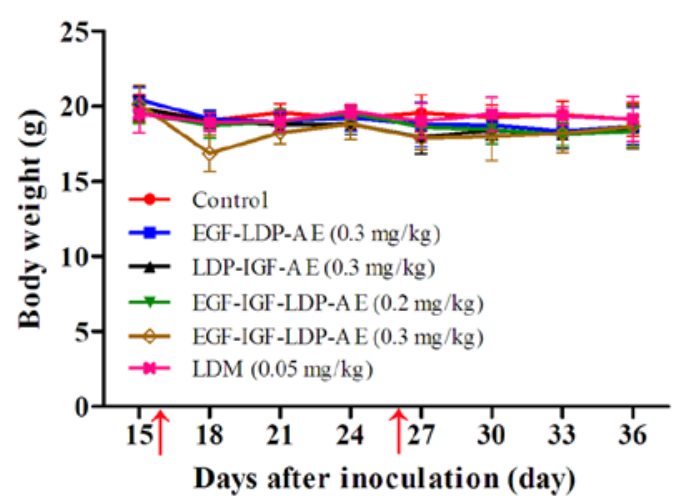

Figure 7. In vivo efficacies of LDM and enediyne-energized fusion proteins EGF-LDP-IGF-AE, EGF-LDP-AE and LDP-IGF-AE. (A) The mean tumor volumes and (B) body weights of mice in each group are shown. Red line: ${ }^{* *} \mathrm{P}<0.01$, control vs. EGF-LDP-IGF-AE (0.2 and $\left.0.3 \mathrm{mg} / \mathrm{kg}\right)$; pink line: ${ }^{* *} \mathrm{P}<0.01$, LDM vs. EGF-LDP-IGF-AE (0.3 mg/kg); blue line: *P<0.05, EGF-LDP-AE (0.3 mg/kg) vs. EGF-LDP-IGF-AE (0.3 mg/kg); black line: *P<0.05, LDP-IGF-AE $(0.3 \mathrm{mg} / \mathrm{kg})$ vs. EGF-LDP-IGF-AE $(0.3 \mathrm{mg} / \mathrm{kg})$; green line: ${ }^{*} \mathrm{P}<0.05$, EGF-LDP-IGF-AE (0.2 mg/kg) vs. EGF-LDP-IGF-AE (0.3 mg/kg). The arrows indicated the time of injection (day 16 and 26).

marked decrease in total AKT and ERK in both KYSE450 and EC9706 cells (Fig. 6A and C).

The effects of mono-specific fusion proteins EGF-LDP-AE and LDP-IGF-AE on EGFR/IGF-1R signaling were also assessed in the KYSE450 and EC9706 cells. Similar to the bispecific fusion protein, EGF-LDP-AE or LDP-IGF-AE treatment for $24 \mathrm{~h}$ did not exhibit effects on the EGFR/ IGF-1R signaling pathways. In KYSE450 cells, activation of EGFR was inhibited after exposure to EGF-LDP-AE or LDP-IGF-AE for 72 and $96 \mathrm{~h}$ whereas p-IGF-1R was upregulated after treatment for 48, 72 and $96 \mathrm{~h}$. The phosphorylation of two downstream molecules AKT and ERK was significantly reduced after treatment for 48, 72 and $96 \mathrm{~h}$. Total expression level of EGFR, IGF-1R, AKT and ERK was decreased when the exposure time was extended to 72 and $96 \mathrm{~h}$ (Fig. 6B). In EC9706 cells, p-EGFR and total EGFR was downregulated only after treatment for $96 \mathrm{~h}$. Levels of p-IGF-1R, p-AKT and p-ERK were significantly altered after treatment for 48, 72 and $96 \mathrm{~h}$, in which p-IGF-1R was increased and p-AKT and -ERK were decreased (Fig. 6D).

Efficacy of enediyne-energized fusion proteins in vivo. In vivo antitumor efficacy of both bispecific and mono-specific enediyne-energized fusion proteins was investigated in a human esophageal cancer KYSE450 xenograft nude mouse model. As shown in Fig. 7A, LDM, EGF-LDP-IGF-AE, EGF-LDP-AE and LDP-IGF-AE significantly suppressed the growth of KYSE450 xenografts. The bispecific fusion protein EGF-LDP-IGF-AE at dosages of 0.2 and $0.3 \mathrm{mg} / \mathrm{kg}$ inhibited the growth of xenografts by 64.1 and $75.1 \%$, respectively $(\mathrm{P}<0.01$ compared with the $\mathrm{PBS}$-treated group; $\mathrm{P}<0.05$ between the two EGF-LDP-IGF-AE-treatment groups at different dosages). Furthermore, the EGF-LDP-IGF-AE-treated group at the dosage $0.3 \mathrm{mg} / \mathrm{kg}$ showed statistically significant differences $(\mathrm{P}<0.01)$ compared with the LDM-treated group at the maximum tolerated dosage $(0.05 \mathrm{mg} / \mathrm{kg}$, inhibition rate, $57.8 \%$ ). Mono-specific fusion proteins EGF-LDP-AE and LDP-IGF-AE at a dosage of $0.3 \mathrm{mg} / \mathrm{kg}$ demonstrated similar tumor growth inhibition to bispecific EGF-LDP-IGF-AE protein at a dosage of $0.2 \mathrm{mg} / \mathrm{kg}$ (inhibition rates of 61.2 and $62.6 \%$ for EGF-LDP-AE and LDP-IGF-AE respectively). However, when given at the same dosage $(0.3 \mathrm{mg} / \mathrm{kg})$, the EGF-LDP-IGF-AE-treated group showed more significant tumor growth inhibition compared with the mono-specific counterparts $(\mathrm{P}<0.05)$. No animals died in all groups, and body weight curves showed that the animals tolerated well the administered dosage of the fusion proteins (Fig. 7B).

\section{Discussion}

Results from the human ESCC tissue microarray detection in the present study and other previous studies, have revealed that EGFR and IGF-1R are highly co-expressed in ESCC. In addition, the abnormal expression of these receptors is associated with reduced survival, increased risk of relapse and poor prognosis $(10,12)$. Therefore, various EGFR-targeted drugs including monoclonal antibodies (mAbs, cetuximab and panitumumab) and tyrosine kinase inhibitors (TKIs; gefitinib and erlotinib) have been examined in the clinical for esophageal cancer patients. However, the efficacy was far from satisfactory (17-21). Since the crosstalk between EGFR and IGF-1R pathways exist, strategies of the dual-inhibition of both pathways have been pursued for enhanced antitumor efficacy. Strategies include: i) the combination of mAbs or TKIs against different growth factors or receptor tyrosine kinases (RTKs); and ii) bispecific drugs targeting two molecules. Improved antitumor efficacy has been achieved by the combination of mono-specific therapeutic compounds involved in the inhibition of tumor growth, metastasis and anti-angiogenesis (27-30). However, the combination therapy requires the development of individual or combinatorial drugs, which requires a significant investment for production, preclinical and clinical studies. Moreover, some combinations may increase the toxicity and shorten progression-free survival compared to administration of single drugs, such as bevacizumab with panitumumab or cetuximab in advanced colorectal cancer $(31,32)$. Dual targeting strategies with bispecific agents have been classified into two types: i) those that directly act on target molecules, 
such as bispecific antibodies and ii) those that depend on targets for delivering an active moiety to killing tumor cells, such as bispecific immunotoxins or fusion proteins. A number of bispecific antibodies targeting both EGFR and IGF-1R (EI-04 and XGFR) have demonstrated superior antitumor activity in preclinical models $(33,34)$, and bispecific immunotoxins/fusion proteins developed by Vallera et al also demonstrated either enhanced antitumor activity or broader spectrum of reactivity than the mono-specific molecules (35-37). EGF-LDP-IGF-AE is a bispecific enediyne-energized fusion protein that was constructed by fusing the natural ligands of EGFR and IGF-1R (EGF and IGF-1) to an enediyne antibiotic lidamycin (LDM; C1027) with potent antitumor activity. There are two advantages of EGF-LDP-IGF-AE over the mono-specific fusion proteins. Firstly, the two ligands were designed for receptor binding and subsequent intracellular delivery of the 'warhead', and the LDM acts as toxic moiety for killing tumor cells. The dual-targeting characteristics and the inclusion of the potent cytotoxic payload provide the EGF-LDP-IGF-AE with improved tumor selectivity and enhanced cytotoxicity. Secondly, due to the presence of small targeting ligands (EGF, $6.2 \mathrm{kDa}$ and IGF, 7.6 kDa) and small cytotoxin (LDM, $15 \mathrm{kDa}$ ), the EGF-LDP-IGF-AE protein is composed of 253 amino acids with a molecular weight of $27.1 \mathrm{kDa}$, and the smaller size provides it with enhanced solid tumor penetration, increased tumor uptake and lower immunogenicity. As a result, the bispecific fusion protein EGF-LDP-IGF-AE exhibited potent antitumor efficacy against esophageal cancer.

Binding with EGFR and IGF-1R and internalization were the prerequisites for EGF-LDP-IGF-AE to exhibit its tumor cell-selective cytotoxicity. The results from the immunofluorescent staining assay showed that green fluorescence was located in the membrane and cytoplasm of the ESCC cells, which indicated that the EGF-LDP-IGF protein could bind with the receptors on the cell membrane and then internalize into the cytoplasm through receptor-mediated endocytosis. The bispecific fusion protein EGF-LDP-IGF-AE showed extremely potent cy totoxicity to ESCC cells in vitro. However, the correlation analysis revealed that there was no significant correlation between the $\mathrm{IC}_{50}$ values of EGF-LDP-IGF-AE and the p-EGFR, p-IGF-1R and total EGFR and IGF-1R expression levels. Similar results were also reported by other studies concerning targeted drugs, such as erlotinib and lapatinib $(38,39)$. We speculated that the mechanisms underlying the internalization of EGF-LDP-IGF-AE into the tumor cells was mainly dependent on receptor-mediated endocytosis. Yet, the AE molecules may dissociate from the EGF-LDP-IGF protein outside the cells, and then the small naked AE molecules enter the cells in receptor-independent mechanisms. This assumption will be further investigated, and the identification of the key molecules to predict the responsiveness to EGF-LDP-IGF-AE may be another focus of further research. This may allow identification of patients who may benefit from the EGF-LDP-IGF-AE-targeted therapy.

In vitro, two-way ANOVA analysis revealed that bispecific EGF-LDP-IGF-AE had stronger cytotoxicity than mono-specific fusion protein EGF-LDP-AE in four ESCC cell lines, but the differences between EGF-LDP-IGF-AE and another mono-specific fusion protein LDP-IGF-AE in
KYSE450 and KYSE510 cells were not significant. Actually, LDP-IGF-AE protein was more cytotoxic than EGF-LDP-AE in all ESCC cell lines $(\mathrm{P}<0.05)$. The cytotoxicity of fusion proteins depended on the presence of the active enediyne chromophore (AE); therefore, the reconstitution efficiency of $\mathrm{AE}$ to fusion protein EGF-LDP or LDP-IGF was closely related to their cytotoxicity. The protein structure of EGF-LDP may affect its reconstitution efficiency, resulting in the lower cytotoxicity. Results from the in vivo experiments also revealed a more significant tumor growth inhibition following the EGF-LDP-IGF-AE treatment. EGF-LDP-IGF-AE at a dosage of $0.3 \mathrm{mg} / \mathrm{kg}$ yielded tumor growth inhibition of $75.1 \%$, which showed a statistically significant difference compared with the LDM-treated group $(\mathrm{P}<0.01)$ and mono-specific fusion protein-treated groups $(\mathrm{P}<0.05)$. Furthermore, no mice died in the EGF-LDP-IGF-AE-treated group and weight loss in the mice at the termination of the experiment did not exceed $10 \%$ of the pretreatment weight, which indicated that nude mice tolerated well the EGF-LDP-IGF-AE at a dosage of $0.3 \mathrm{mg} /$ $\mathrm{kg}$. This dosage was six times the maximum tolerated dose of LDM. These results revealed that bispecific EGF-LDPIGF-AE protein was less toxic to normal tissues than naked LDM in vivo, and this may be due to the capacity of binding the two receptors of the bispecific protein. Therefore, it preferably bound to the tumor cells highly expressing both receptors instead of binding to normal cells with low expression of one or both receptors. In addition, bispecific fusion proteins may extend the patient coverage which is economically advantageous, as a portion of patients may have EGFR overexpression whereas IGF-1R overexpression may be present in another portion of patients.

To illuminate the mechanisms underlying the cytotoxic effects of EGF-LDP-IGF-AE on ESCC cells, PI and Annexin V-FITC/PI staining assays were used to determine cell cycle arrest and cell apoptosis, and the effects on EGFR/IGF-1R signaling was analyzed by western blotting. The data from cell cycle analysis indicated that EGF-LDP-IGF-AE caused a significant G2/M arrest in the EC9706, TE-1 and KYSE510 cells and a G1 arrest in the KYSE450 cells following $0.1 \mathrm{nmol} / 1$ EGF-LDP-IGF-AE treatment. Additionally, EGF-LDP-IGF-AE also induced significant apoptosis in the ESCC cells in a concentration-dependent manner. After treatment with EGF-LDP-IGF-AE for 48, 72 and 96 h, activation of EGFR and the two key downstream signaling molecules AKT and ERK was inhibited and the signal transduction was blocked. However, the level of p-IGF-1R was significantly increased after exposure to EGF-LDP-IGF-AE for 48, 72 and $96 \mathrm{~h}$. This phenomenon could be explained by the fact that EGF-LDPIGF-AE treatment activated IGF-1R by phosphorylation. Then the activated IGF-1R internalized into the cytoplasm and was transported to the lysosome for degradation. As a result, the cell surface IGF-1R was greatly reduced which resulted in a significant decrease in the interactions between IGF ligands and IGF-1R. Therefore, the signaling pathways mediated by IGF-1R were inhibited. The total IGF-1R expression was reduced after treatment with EGF-LDP-IGF-AE which confirmed our speculation.

In summary, bispecific fusion protein EGF-LDP-IGF-AE demonstrated potent cytotoxicity to ESCC cells and caused 
significant cell cycle arrest and apoptosis in vitro. It also showed high efficacy in suppressing the growth of human esophageal cancer xenografts in vivo. These findings suggest that EGF-LDP-IGF-AE may be a potential candidate for esophageal cancer therapy, which may be developed further for clinical application.

\section{Acknowledgements}

The present study was supported by a grant from the National Science Foundation of China (no. 81202447), and the Support Project for Talents of Science and Technology Innovation in Universities of Henan (no. 15HASTIT040).

\section{References}

1. Homs MY, Voest EE and Siersema PD: Emerging drugs for esophageal cancer. Expert Opin Emerg Drugs 14: 329-339, 2009.

2. Wang LD, Zhou FY, Li XM, Sun LD, Song X, Jin Y, Li JM, Kong GQ, Qi H, Cui J, et al: Genome-wide association study of esophageal squamous cell carcinoma in Chinese subjects identifies susceptibility loci at PLCE1 and C20orf54. Nat Genet 42: 759-763, 2010.

3. Pennathur A, Gibson MK, Jobe BA and Luketich JD: Oesophageal carcinoma. Lancet 381: 400-412, 2013.

4. Rowinsky EK: The erbB family: Targets for therapeutic development against cancer and therapeutic strategies using monoclonal antibodies and tyrosine kinase inhibitors. Annu Rev Med 55: 433-457, 2004.

5. Hirsch FR, Varella-Garcia M, Bunn PA Jr, Di Maria MV, Veve R, Bremmes RM, Barón AE, Zeng C and Franklin WA: Epidermal growth factor receptor in non-small-cell lung carcinomas: Correlation between gene copy number and protein expression and impact on prognosis. J Clin Oncol 21: 3798-3807, 2003.

6. Oliveira-Silva RJ, Carolina de Carvalho A, de Souza Viana L, Carvalho AL and Reis RM: Anti-EGFR therapy: Strategies in head and neck squamous cell carcinoma. Recent Patents Anticancer Drug Discov 11: 170-183, 2016.

7. Ooi A, Takehana T, Li X, Suzuki S, Kunitomo K, Iino H, Fujii H, Takeda Y and Dobashi Y: Protein overexpression and gene amplification of $H E R-2$ and $E G F R$ in colorectal cancers: An immunohistochemical and fluorescent in situ hybridization study. Mod Pathol 17: 895-904, 2004.

8. DiGiovanna MP, Stern DF, Edgerton SM, Whalen SG, Moore D II and Thor AD: Relationship of epidermal growth factor receptor expression to ErbB-2 signaling activity and prognosis in breast cancer patients. J Clin Oncol 23: 1152-1160, 2005.

9. Sheng Q and Liu J: The therapeutic potential of targeting the EGFR family in epithelial ovarian cancer. Br J Cancer 104: 1241-1245, 2011.

10. Moorcraft SY and Chau I: Investigational therapies targeting the ErbB family in oesophagogastric cancer. Expert Opin Investig Drugs 23: 1349-1363, 2014

11. Yin M, Guan X, Liao Z and Wei Q: Insulin-like growth factor-1 receptor-targeted therapy for non-small cell lung cancer: A mini review. Am J Transl Res 1: 101-114, 2009.

12. Adachi $Y$, Ohashi H, Imsumran A, Yamamoto H, Matsunaga $Y$, Taniguchi H, Nosho K, Suzuki H, Sasaki Y, Arimura Y, et al: The effect of IGF-I receptor blockade for human esophageal squamous cell carcinoma and adenocarcinoma. Tumour Biol 35: 973-985, 2014.

13. Ludovini V, Bellezza G, Pistola L, Bianconi F, Di Carlo L, Sidoni A, Semeraro A, Del Sordo R, Tofanetti FR, Mameli MG, et al: High coexpression of both insulin-like growth factor receptor-1 (IGFR-1) and epidermal growth factor receptor (EGFR) is associated with shorter disease-free survival in resected non-small-cell lung cancer patients. Ann Oncol 20: 842-849, 2009.

14. Takahari D, Yamada Y, Okita NT, Honda T, Hirashima Y, Matsubara J, Takashima A, Kato K, Hamaguchi T, Shirao K, et al: Relationships of insulin-like growth factor-1 receptor and epidermal growth factor receptor expression to clinical outcomes in patients with colorectal cancer. Oncology 76: $42-48,2009$
15. Xu L, Qi Y, Xu Y, Lian J, Wang X, Ning G, Wang W and Zhu Y: Co-inhibition of EGFR and IGF1R synergistically impacts therapeutically on adrenocortical carcinoma. Oncotarget 7: 36235-36246, 2016.

16. Valsecchi ME, McDonald M, Brody JR, Hyslop T, Freydin B, Yeo CJ, Solomides C, Peiper SC and Witkiewicz AK: Epidermal growth factor receptor and insulinlike growth factor 1 receptor expression predict poor survival in pancreatic ductal adenocarcinoma. Cancer 118: 3484-3493, 2012.

17. Dutton SJ, Ferry DR, Blazeby JM, Abbas H, Dahle-Smith A, Mansoor W, Thompson J, Harrison M, Chatterjee A, Falk S, et al: Gefitinib for oesophageal cancer progressing after chemotherapy (COG): A phase 3, multicentre, double-blind, placebo-controlled randomised trial. Lancet Oncol 15: 894-904, 2014.

18. Chan JA, Blaszkowsky LS, Enzinger PC, Ryan DP, Abrams TA, Zhu AX, Temel JS, Schrag D, Bhargava P, Meyerhardt JA, et al: A multicenter phase II trial of single-agent cetuximab in advanced esophageal and gastric adenocarcinoma. Ann Oncol 22: 1367-1373, 2011.

19. Lorenzen S, Schuster T, Porschen R, Al-Batran SE, Hofheinz R, Thuss-Patience P, Moehler M, Grabowski P, Arnold D, Greten T, et al: Cetuximab plus cisplatin-5-fluorouracil versus cisplatin-5-fluorouracil alone in first-line metastatic squamous cell carcinoma of the esophagus: A randomized phase II study of the Arbeitsgemeinschaft Internistische Onkologie. Ann Oncol 20: 1667-1673, 2009.

20. Bendell JC, Meluch A, Peyton J, Rubin M, Waterhouse D, Webb C, Burris HA III and Hainsworth JD: A phase II trial of preoperative concurrent chemotherapy/radiation therapy plus bevacizumab/erlotinib in the treatment of localized esophageal cancer. Clin Adv Hematol Oncol 10: 430-437, 2012.

21. Tebbutt NC, Price TJ, Ferraro DA, Wong N, Veillard AS, Hall M, Sjoquist KM, Pavlakis N, Strickland A, Varma SC, et al: Panitumumab added to docetaxel, cisplatin and fluoropyrimidine in oesophagogastric cancer: ATTAX3 phase II trial. Br J Cancer 114: 505-509, 2016.

22. Krop IE, Lin NU, Blackwell K, Guardino E, Huober J, Lu M, Miles D, Samant M, Welslau M and Diéras V: Trastuzumab emtansine (T-DM1) versus lapatinib plus capecitabine in patients with HER2-positive metastatic breast cancer and central nervous system metastases: A retrospective, exploratory analysis in EMILIA. Ann Oncol 26: 113-119, 2015.

23. Guo XF, Zhu XF, Cao HY, Zhong GS, Li L, Deng BG, Chen P, Wang PZ, Miao QF and Zhen YS: A bispecific enediyneenergized fusion protein targeting both epidermal growth factor receptor and insulin-like growth factor 1 receptor showing enhanced antitumor efficacy against non-small cell lung cancer. Oncotarget 8: 27286-27299, 2017.

24. Shao RG and Zhen YS: Enediyne anticancer antibiotic lidamycin: Chemistry, biology and pharmacology. Anticancer Agents Med Chem 8: 123-131, 2008.

25. Budwit-Novotny DA, McCarty KS, Cox EB, Soper JT, Mutch DG, Creasman WT, Flowers JL and McCarty KS Jr: Immunohistochemical analyses of estrogen receptor in endometrial adenocarcinoma using a monoclonal antibody. Cancer Res 46: 5419-5425, 1986.

26. Guo XF, Zhu XF, Shang Y, Zhang SH and Zhen YS: A bispecific enediyne-energized fusion protein containing ligand-based and antibody-based oligopeptides against epidermal growth factor receptor and human epidermal growth factor receptor 2 shows potent antitumor activity. Clin Cancer Res 16: 2085-2094, 2010.

27. Okita R, Shimizu K, Nojima Y, Yukawa T, Maeda A, Saisho S and Nakata M: Lapatinib enhances trastuzumab-mediated antibody-dependent cellular cytotoxicity via upregulation of HER2 in malignant mesothelioma cells. Oncol Rep 34: 2864-2870, 2015.

28. Wang CJ, Tong PJ and Zhu MY: The combinational therapy of trastuzumab and cetuximab inhibits tumor growth in a patientderived tumor xenograft model of gastric cancer. Clin Transl Oncol 18: 507-514, 2016.

29. Nahta R, Hung MCC and Esteva FJ: The HER-2-targeting antibodies trastuzumab and pertuzumab synergistically inhibit the survival of breast cancer cells. Cancer Res 64: 2343-2346, 2004.

30. Larkin J, Chiarion-Sileni V, Gonzalez R, Grob JJ, Cowey CL, Lao CD, Schadendorf D, Dummer R, Smylie M, Rutkowski P, et al: Combined nivolumab and ipilimumab or monotherapy in untreated melanoma. N Engl J Med 373: 23-34, 2015. 
31. Hecht JR, Mitchell E, Chidiac T, Scroggin C, Hagenstad C, Spigel D, Marshall J, Cohn A, McCollum D, Stella P, et al: A randomized phase IIIB trial of chemotherapy, bevacizumab, and panitumumab compared with chemotherapy and bevacizumab alone for metastatic colorectal cancer. J Clin Oncol 27: 672-680, 2009.

32. Stopeck AT, Unger JM, Rimsza LM, LeBlanc M, Farnsworth B, Iannone M, Glenn MJ, Fisher RI and Miller TP: A phase 2 trial of standard-dose cyclophosphamide, doxorubicin, vincristine, prednisone (CHOP) and rituximab plus bevacizumab for patients with newly diagnosed diffuse large B-cell non-Hodgkin lymphoma: SWOG 0515. Blood 120: 1210-1217, 2012.

33. Dong J, Sereno A, Aivazian D, Langley E, Miller BR, Snyder WB, Chan E, Cantele M, Morena R, Joseph IB, et al: A stable IgG-like bispecific antibody targeting the epidermal growth factor receptor and the type I insulin-like growth factor receptor demonstrates superior anti-tumor activity. MAbs 3: 273-288, 2011.

34. Schanzer JM, Wartha K, Moessner E, Hosse RJ, Moser S, Croasdale R, Trochanowska H, Shao C, Wang P, Shi L, et al: XGFR*, a novel affinity-matured bispecific antibody targeting IGF-1R and EGFR with combined signaling inhibition and enhanced immune activation for the treatment of pancreatic cancer. MAbs 8: 811-827, 2016.

35. Tsai AK, Oh S, Chen H, Shu Y, Ohlfest JR and Vallera DA: A novel bispecific ligand-directed toxin designed to simultaneously target EGFR on human glioblastoma cells and uPAR on tumor neovasculature. J Neurooncol 103: 255-266, 2011.
36. Huang J, Li YM, Massague J, Sicheneder A, Vallera DA and Hall WA: Intracerebral infusion of the bispecific targeted toxin DTATEGF in a mouse xenograft model of a human metastatic non-small cell lung cancer. J Neurooncol 109: 229-238, 2012.

37. Oh S, Stish BJ, Sachdev D, Chen H, Dudek AZ and Vallera DA: A novel reduced immunogenicity bispecific targeted toxin simultaneously recognizing human epidermal growth factor and interleukin-4 receptors in a mouse model of metastatic breast carcinoma. Clin Cancer Res 15: 6137-6147, 2009.

38. López-Ayllón BD, de Castro-Carpeño J, Rodriguez C, Pernía O, Ibañez de Cáceres I, Belda-Iniesta C, Perona R and Sastre L: Biomarkers of erlotinib response in non-small cell lung cancer tumors that do not harbor the more common epidermal growth factor receptor mutations. Int J Clin Exp Pathol 8: 2888-2898, 2015.

39. Rusnak DW, Alligood KJ, Mullin RJ, Spehar GM, Arenas-Elliott C, Martin AM, Degenhardt Y, Rudolph SK, Haws TF Jr, HudsonCurtis BL, et al: Assessment of epidermal growth factor receptor (EGFR, ErbB1) and HER2 (ErbB2) protein expression levels and response to lapatinib (Tykerb, GW572016) in an expanded panel of human normal and tumour cell lines. Cell Prolif 40: 580-594, 2007. 